\title{
COMMUNITY PSYCHOLOGY PERSPECTIVES ON SOCIAL CAPITAL THEORY AND COMMUNITY DEVELOPMENT PRACTICE
}

\author{
By Douglas D. Perkins, Joseph Hughey, \\ and Paul W. Speer
}

\begin{abstract}
Concepts and research from community psychology can inform community development practice by reframing social capital theory. Social capital (SC) is generally defined and measured at the interpersonal, community, institutional, or societal levels in terms of networks (bridging) and norms of reciprocity and trust (bonding) within those networks. SC should be analyzed in a multi-level ecological framework in terms of both individual psychological and behavioral conceptions (sense of community, collective efficacy-or empowerment, neighboring, and citizen participation) and institutional and community network-level conceptions. Excessive concern for social cohesion undermines the ability to confront or engage in necessary conflict, and thus, it dis-empowers the community. Instead of emphasizing social cohesion, "network-bridging" opportunities to increase power, access, and learning should be emphasized. Institutional and community network analysis shows how SC operates at those levels and where to target service resources and develop mediating structures. Psychological and behavioral factors point to factors that motivate individuals to engage in building SC and methods to maintain and improve that engagement.
\end{abstract}

Keywords: community psychology, social capital theory, sense of community, collective efficacy, empowerment, neighboring, citizen participation, community institutions, networks, mediating structures

Douglas D. Perkins is an Associate Professor at Vanderbilt University. Joseph Hughey is an Associate Professor at the University of Missouri-Kansas City. Paul W. Speer is an Associate Professor at Vanderbilt University.

Authors' note: This paper is part of an interdisciplinary collaborative initiative between the Society for Community Research and Action (the major professional organization of community psychologists) and the Community Development Society. A portion of this paper was presented at the Annual Conference of the Community Development Society, July 2000, St. John, New Brunswick, Canada. The authors thank anonymous reviewers and Ted Bradshaw for their helpful comments. All correspondence: Douglas D. Perkins, Program in Community Research \& Action, HOD, Peabody College-Box 90, Vanderbilt University, Nashville, TN 37203, or doug.perkins@vanderbilt.edu. 


\section{INTRODUCTION}

We review concepts and research from community psychology, a field still unfamiliar to most practitioners and academics in community development, in order to reframe social capital (SC) theory and community development practice. The SC concept grew out of the sociology of education (Bourdieu, 1985; Coleman, 1988) but quickly spread to the rest of the social sciences and into the community development literature (Falk \& Kilpatrick, 2000; Flora, 1998). It has been discussed broadly, but is generally defined and measured at the interpersonal, community, institutional, or societal levels in terms of both bridging and bonding social connections (Gittell \& Vidal, 1998; Narayan, 1999; Putnam, 2000; Saegert, Thompson \& Warren, 2001). Bridging most often refers to relationships among local institutions, but individuals' connections with those institutions and with each other must not be ignored or taken for granted. Bonding is described by SC theorists as norms of reciprocity and trust within those networks.

Although psychology has been much slower to embrace the SC concept, community psychologists have extensively studied aspects of it at the individual level, but under other rubrics. As we will explain, individual SC consists of both informal, community-focused attitudes (sense of community) and behaviors (neighboring), as well as formally organized behaviors (citizen participation) and attitudes about those organizations and behaviors (collective efficacy — or empowerment). Other, related psychological concepts, such as social support, communitarianism, place attachment, and community satisfaction, pride, and confidence also have relevance to SC and community development practice.

Psychological factors point to what motivates individuals to participate in particular settings and behaviors, how to maintain that participation, and how those motivations and behaviors interact with various setting and organizational characteristics to promote effective SC. Similar to the notion of "learning organizations" (Argyris, 1993) and "learning communities" (Falk \& Harrison, 1998), psychosocial/behavioral factors operate simultaneously at individual, organizational, and community levels of analysis. Institutional and community factors point to how SC operates at those levels, where to target service resources, and how to organize and support mediating structures. ${ }^{1}$ Our framework helps to distinguish key differences in forms of SC. For example, too much concern for cohesion, which is more a focus of the informal components of $\mathrm{SC}$ than the formal components, may undermine the ability to confront or engage in necessary conflict within and between groups and thus dis-empower those groups.

Hence, we argue two fundamental points of clarification: (1) SC should be analyzed in a multi-level framework in terms of both (a) individual psychological and behavioral conceptions and (b) institutional and community network-level conceptions; (2) interpersonal bonding is useful as a catalyst for participation 
and commitment, but network bridging opportunities that increase power, access, and learning deserve greater emphasis.

\section{Community Psychology}

Before describing concepts from community psychology, some context may be helpful. The roots of community psychology in the United States lie in the social and political changes of the community-based civil rights, anti-poverty, and de-institutionalization movements and programs of the 1950s and 1960s. The major professional association of community psychologists is the Society for Community Research and Action (SCRA). ${ }^{2}$ One of SCRA's official goals is "to engage in action, research, and practice committed to liberating oppressed peoples and respecting all cultures." Community psychology has always been more multi-disciplinary than most other areas of psychology and has only become more so over the years.

The fields of community psychology and community development share a concern for addressing social problems at the local level. They also share many of the same basic tenets and values, including a strengths or asset-based, rather than deficit, orientation (Kretzmann \& McKnight, 1993; Perkins, Crim, Silberman \& Brown, in press); an understanding and appreciation of the value of human diversity; a proactive focus on prevention, public health, self-help, and the common good; and individual and community participation and empowerment as goals (Christenson \& Robinson, 1989; Dalton, Elias \& Wandersman, 2001; Friedmann, 1992). Yet, because of separate disciplinary lineages, each field remains largely ignorant of the other. This is unfortunate as they both have much to gain from exploring opportunities for interdisciplinary and organizational communication and collaboration. Community development has much to offer community psychology, especially in terms of applied expertise and attention to economic and sociological factors. Likewise, community psychology has much to offer community development, especially in terms of research and evaluation expertise and the role of psychological and behavioral factors. Both fields have much to offer in terms of theories relevant to each other's work.

\section{SOCIAL CAPITAL: A MULTI-LEVEL, PSYCHOLOGICAL- ECOLOGICAL RE-CONCEPTUALIZATION}

One such theory is social capital-the norms, networks, and mutual trust of "civil society" facilitating cooperative action among citizens and institutions (Coleman, 1988; Putnam, 2000). SC has not caught on in community psychology, as it has in community development, for several reasons. First, as discussed below, community psychologists have long and thoroughly studied a variety of community-focused behaviors and attitudes related to SC. They, therefore, may be skeptical of a new, quasi-economic term, which seems to cover familiar ground and for which there appears to be no clear, precise, and agreed upon definition. The reason SC is ambiguous and controversial is that it has 
been defined differently to suit different ends, or left undefined. Similar to the terms empowerment, sense of community, and sustainability, $\mathrm{SC}$ has become to most a vague buzzword, used by different people to mean many different things and thus to mean very little.

Second, some skeptics may be concerned about the potential SC has already shown for being co-opted by anti-government, neo-conservatives as a means of reducing public spending on even critically needed social services. For example, the Social Capital Enhancement Act, proposed a few years ago in the Utah state legislature, would have required government workers to turn away all first requests for services, no matter how legitimate, and forced those in need to look first to the private sector.

The third and probably greatest reason for community psychologists' inattention to SC is that it was conceived in sociology and spread to political science and economics, but until now, it has not been interpreted in explicitly psychological terms. A related problem is that community psychology focuses primarily on the experience, behavior, and well being of individuals in the context of groups/settings, community organizations, and other larger levels of analysis. SC seemed to be about context (networks of individuals and organizations) without much specific concern about individuals.

The idea that SC is only about social structures and networks and not individuals is far too constraining, of course. The above definition refers to "norms, networks, mutual trust, and cooperative action"-each of which has been the focus of considerable psychological inquiry. Indeed, SC operates at an individual, or micro-social, level and a collective, or meso- and macro-social, level (Borgatti, Jones \& Everett, 1998). Our purpose is to elaborate on both of these from a community psychology perspective. First is an understanding of $\mathrm{SC}$ as the value of an individual's social relationships. This perspective draws on notions of social support, sense of community, material and informational resources, and psychological empowerment. In this conceptualization, benefits that accrue to individuals result from their relationships and civic participation. Second is the understanding of SC as a quality of groups, networks, institutions, communities, and societies. This perspective emphasizes the collective nature of the phenomena - the norms of reciprocity or the degree of social integration within and between settings.

\section{Social Capital at the Individual Level of Cognitions and Behaviors}

Two of the first psychologists to focus on SC measured it in individual behavioral terms focusing on both informal neighborly behaviors and formally organized participation and leadership activity (Saegert \& Winkel, 1998). They found that SC, as a whole, significantly predicted the revitalization and up-keep of distressed inner-city housing. 
We like their formal-informal distinction, which loosely relates to the bridging (formal) and bonding (informal) functions of SC, but would add two cognitive dimensions to the behavioral ones. Community psychologists have studied many individual-level attitudes, emotions, and perceptions related to $\mathrm{SC}$, the most popular being empowerment and sense of community. Empowerment is about the development of a sense of collective efficacy, or control over the institutions that affect one's life. Sense of community is an attitude of bonding, or mutual trust and belonging, with other members of one's group or locale. Thus, following Perkins and Long (2002), we add the idea of formal and informal community "trust"—or the community-focused cognitive (perceptual and meaning-making) processes of individuals - to formal and informal pro-social community behaviors (see Figure 1). This framework results in a four-part definition of SC at the individual, psychological level. The two cognitive components are (1) trust in one's neighbors (sense of community), and (2) belief in the efficacy of formally organized action (empowerment). The two behavioral components are (3) informal neighboring behavior, and (4) formal participation in community organizations. Each dimension of individual-level $\mathrm{SC}$ is distinct but related to the others.

\section{FIGURE 1. Four Dimensions of Individual-level Social Capital}

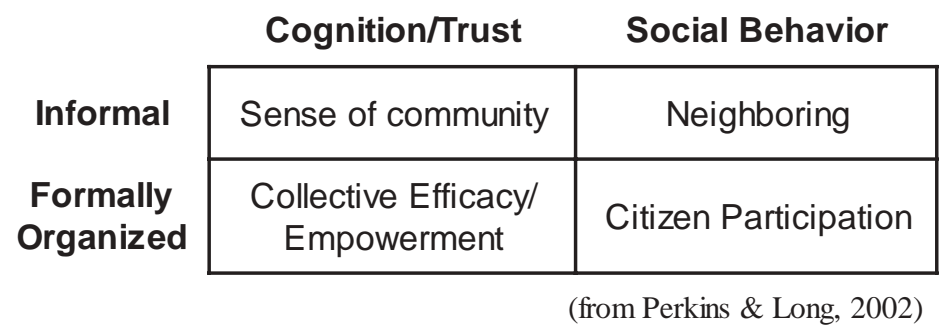

Sense of community (informal-cognition cell of Figure 1) has been studied by community researchers in many different countries, including Australia (Chipuer \& Pretty, 1999; Fisher \& Sonn, 2002), Canada (Pretty, 1990), Israel (Itzhaky \& York, 2000), Italy (Prezza, Amici, Roberti, \& Tedeschi, 2001), Taiwan (Li, 1998), the United Kingdom (Sampson, 1991), the United States, and Venezuela (Garcia, Giuliani, \& Wiesenfeld, 1999). Many community researchers have borrowed McMillan and Chavis' (1986) definition of a psychological sense of community as including four dimensions: membership, shared emotional connection, influence, and needs fulfillment. Others have narrowed the definition to social connections, mutual concerns, and community values (Perkins \& Long, 2002), or offered a more dynamic perspective that better captures community change in terms of shared history, common symbols, and ongoing development (Fisher \& Sonn, 2002). 
A sense of community is a widely valued indicator of quality of community life and a consistent catalyst for both behavioral dimensions of SC: organized participation and informal neighboring (Chavis \& Wandersman, 1990; Garcia, Giuliani, \& Wiesenfeld, 1999; Itzhaky, \& York, 2000; Perkins et al., 1990; Prezza, Amici, Roberti, \& Tedeschi, 2001; Wandersman \& Giamartino, 1980). The link with organized participation has been found at both the individual and community levels of analysis (Brodsky et al., 1999; Perkins, Brown, \& Taylor, 1996; Perkins \& Long, 2002). Participation, in turn, may enhance sense of community (Hughey, Speer, \& Peterson, 1999). Sense of community has also been linked with empowerment, in both the organizational (Speer, Jackson \& Peterson, 2001) and neighborhood contexts (Chavis \& Wandersman, 1990; Perkins \& Long, 2002). Other correlates include community satisfaction and local friendships (Perkins et al., 1990; Sampson, 1991), residential social climate and well-being (Pretty, 1990), communitarianism, informal social control, and less fear of crime, litter, and graffiti (Perkins et al., 1990), type of common land (Li, 1998), minority community identity (Sonn \& Fisher, 1998), investment in home and community building processes (Garcia et al., 1999), and more life satisfaction and less loneliness (Prezza et al., 2001).

Much of this research has been documented in a series of special issues on sense of community starting in 1986 in the Journal of Community Psychology. The latest on the topic has just been collected in an edited volume (Fisher, Sonn, \& Bishop, 2002). It addresses a range of theoretical issues, including the need to define more precisely the community of interest (including both locational and relational communities). The methodology of research on sense of community is another major focus, with some calling for greater use of qualitative and, especially, narrative-based methods, while others support advances in quantitative methods (including community-level measures and multi-level analysis; Perkins \& Long, 2002). What scholars generally agree on is the need for mixed methods that are sensitive to the ecological context of psychological community building. One of the hallmarks that community psychology shares with community development is an ecological orientationa perspective that draws our attention to the multiple (social, economic, political, spatial) and layered contexts (levels of analysis), and dynamic processes of social phenomena (Perkins et al., in press). The practical implications of sense of community are many and varied. For example, two chapters take a human development perspective in examining adolescents' sense of community and find that the organization and activities of schools (Bateman, 2002), as well as places to congregate outside of school (Pretty, 2002), are critical factors in the development of sense of community, which may lead to life-long commitments to community and service.

Collective efficacy (empowerment; formal-cognition cell of Figure 1), or trust in the effectiveness of organized community action, has been studied and applied widely in community development, community psychology, and 
many other fields (Fawcett et al., 1995; Kroeker, 1995; Maton \& Salem, 1995; Perkins, 1995; Perkins et al., 1996; Saegert \& Winkel, 1996; Speer \& Hughey, 1995). Empowerment has been defined as a process by which people gain control over their lives and their community (Rappaport, 1987) and gain a critical understanding of their environment (Zimmerman et al., 1992). It represents a new approach to SC by focusing on the cognitive attributions and motivations that lead community members to engage professionals as collaborators rather than as authoritative experts. It also points to the benefits such an approach has, not only at the individual level, but also in creating empowering and empowered organizations and communities.

Community psychologists have taken an ecological perspective in studying individual, organizational, and community-level participation and empowerment in community organizing (Perkins et al., 1996; Speer \& Hughey, 1995), self-help groups, substance abuse prevention, health promotion, and many other contexts (Perkins \& Zimmerman, 1995). The ideology of empowerment has been widely applied at the state and national policy levels, but with little to no attention to relevant theory or research and with varied success (Perkins, 1995). At the local level, however, it is a natural construct to link with SC as it focuses on how individual self-efficacy, confidence, competencies, and critical reflection relate to group and organization-level bridging via mutual respect, caring, participation, and resource exchange and acquisition, as well as community-level social change (Perkins \& Zimmerman, 1995). In the same study in which SC was found to improve the quality of inner-city, low-income housing (Saegert \& Winkel, 1998), resident participation led to physical improvements, and those improvements, in turn, predicted empowerment and even voting behavior at the group level (Saegert \& Winkel, 1996). At the individual level, empowerment predicts participation, thus creating a mutually reinforcing change process.

Neighboring behavior (informal behavior cell of Figure 1) is the instrumental help we provide, or get from, other community members: for instance, watching a neighbor's house or child, loaning some food or a tool, sharing information, and so forth (Perkins et al., 1990; 1996; Unger \& Wandersman, 1985). Ordinary social interaction with one's neighbors-especially as it helps residents get better acquainted and discuss shared problems, thus encouraging more community involvement, either formally or informally — may also be included as a form of neighboring (Unger \& Wandersman, 1985).

Despite the important role of neighboring to the quality of community life, it is the least studied of the SC factors. However, what evidence exists is compelling. Unger and Wandersman (1983) found that greater neighboring before organizing a block might facilitate subsequent efforts towards forming a block association. In turn, they found that once a block organized, association members engaged in more social interaction. Neighboring is related to participation and the bonding variables: sense of community, communitarianism, 
and community satisfaction (Perkins \& Long, 2002). Perkins et al. (1996) found that neighboring was, generally, the strongest single predictor of participation in community organizations in three cities, cross-sectionally, and one year later, at both the individual and block levels of analysis. Neighboring is especially important for the disenfranchised. Prezza et al. (2001) found that women and those with more children and less education rely more on neighboring relationships.

Social support in the context of stress and coping is a concept similar to neighboring that has been widely studied by community psychologists. It helps to explain the health benefits of both self-help (mutual aid) groups and a sense of community. The roots of both sense of community and social support research in community psychology can be found in crisis theory in which one may develop a stable identity as a long-term member of a community, but one particularly draws upon the social resources of community membership during times of change, challenge, and crisis. The size and quality of one's support network (family, friends, neighbors) are positively related to the avoidance of, or reductions in, a wide variety of stress-related physical and psychological disorders. For example, Briggs (1998) found that adding just one steadily employed adult to a low-income minority adolescent's support network had dramatic effects on perceived access to job and school information/advice (social leverage). Thus, $\mathrm{SC}$ is thought to serve at least three different kinds of social support functions: communal (shared expectations, values, or world view; e.g., sense of community); instrumental (tangible or task-oriented assistance; e.g., neighboring); and informational (access to new information and contacts; Levine $\&$ Perkins, 1997). The fourth form of support, emotional, may also be involved, depending on the quality of one's relationships with community members.

Citizen participation in grassroots organizations constitutes the formal behavioral dimension of SC in Figure 1. Sociologists and political scientists have studied participation but have generally concentrated on its demographics. Psychologists go beyond demographic differences by controlling for them while finding that participants, and their organizations and communities, have a greater sense of collective efficacy or empowerment (Florin \& Wandersman, 1984; Perkins et al., 1996; Saegert \& Winkel, 1996; Speer \& Hughey, 1995), sense of community (Chavis \& Wandersman, 1990; Perkins \& Long, 2002), neighboring (Perkins et al., 1996; Unger \& Wandersman, 1985), community satisfaction (Perkins et al., 1990), and other positive community attachments and organizational bridging activities (Perkins et al., 1996). Relevant organizations include religious congregations (especially community service or advocacy-oriented "social mission" committees; Dokecki, Newbrough, \& O'Gorman, 2001; Foley, McCarthy \& Chaves, 2001; Speer \& Hughey, 1995); school-based associations, citizen advisory boards of government agencies, and youth sports and recreation groups; community councils, resident associations, and community crime and drug prevention coalitions; and self-help groups. 
Participation in community councils, block, neighborhood, and building (tenant or co-op) voluntary associations and other local resident groups is related to stronger communities and participants, in terms of empowerment (Perkins et al., 1996; Saegert \& Winkel, 1996; Speer \& Hughey, 1995), sense of community (Chavis \& Wandersman, 1990), neighboring (Unger \& Wandersman, 1985), and a variety of other positive community attachments and activities (Perkins et al., 1990; 1996). These community development organizations address a wide variety of local needs, from planning and traffic issues to block and park cleanups to youth and recreation programs and community parties to crime prevention. There is consistent evidence across multiple cities, however, that crime may not be an effective issue around which to concentrate community organizing (Perkins et al., 1990; 1996). Block and neighborhood watch groups are common and so we include them as SC. However, they may be most effectively employed in concert with community-oriented policing and, more important, as part of multi-issue, resident community development organizations. We would include, as part of SC, organizations with paid staff as long as a significant portion of the work is done by citizen volunteers. Our point is that communities are not empowered by service and advocacy done on their behalf but only by residents themselves engaging in community action.

\section{Psychological Antecedents to Social Capital}

Just as SC may be more psychological than many theorists and practitioners realize, so too are the precursors to $\mathrm{SC}$ largely psychological. These include a variety of other positive community-oriented cognitions, such as communitarianism, place attachment, community satisfaction, pride of place, and confidence in the future of one's community (Perkins et al., 1996; Perkins \& Long, 2002). Understanding these precursors to SC can help community developers identify what may or may not help in mobilizing a particular community's formal and informal social assets.

Communitarianism is the value placed on one's community and on working collectively to improve it. This term sounds very similar to sense of community. Yet, while communitarianism is empirically related to neighboring and collective efficacy, it is only marginally related to sense of community and participation (Perkins et al., 1990).

The remaining psychological antecedents to SC relate to one's community as a physical place. Place attachments are emotional bonds, developed over time, to particular geographic spaces. Brown and Perkins (1992) used dialectical analysis in suggesting that these bonds are integral to both how we see ourselves as individuals and as a community. Another apparent paradox that place attachments help to resolve is the inherent need for both stability and change in our lives and in our communities. Place attachments lead us to stay and protect what we cherish most in our communities and to invest time, energy, and money to improve that with which we are dissatisfied. The effects are more 
than just physical. Politically, place attachment can lead the most disenfranchised members to participate in community change (Saegert, 1989). Socially, it brings residents together directly or indirectly to address shared concerns (Brown \& Perkins, 1992). "Economically, where residents, through their history in, and attachments to, a place discover what is unique about their community, they can preserve or develop places and events that generate tourism and other business opportunities" (Perkins \& Long, 2002).

Community satisfaction has been studied by psychologists (Hughey \& Bardo, 1987; Miller et al., 1980) as well as by sociologists. It is related to all four individual-level dimensions of SC (sense of community, collective efficacy, neighboring, and citizen participation; Perkins et al., 1990), but is clearly a separate construct (Perkins \& Long, 2002). For example, networking behaviors are motivated by both community bonds and perceived problems (Perkins et al., 1996). It is important to understand that those most aware and critical of local problems are often the most satisfied with their community as a place to live. If those problems are not solved, however, they may eventually lead to community dissatisfaction and disengagement.

Community confidence in the future of the town or neighborhood is a potentially important antecedent to SC, especially in older areas that may be deteriorating and considered "transitional" because of changes in local businesses or residential demography (income, tenure, racial composition). A lack of confidence may spell commercial and residential disinvestment and flight; it may explain why many urban policies and revitalization projects have failed. Confidence is significantly related to collective efficacy, neighboring, participation, sense of community, and resident decisions to move or stay (Perkins \& Long, 2002; Varady, 1986).

\section{Social Capital at the Community Level: Ecology, Institutions and Networks}

Our analysis to this point has brought into sharper focus the psychological dimensions of SC. However, most of psychology focuses too exclusively on individuals, while most other social sciences tend to ignore important individual deviation from group norms. For example, what marginalizes certain people? What makes others become leaders? What makes some of those successful and others not? The ecological orientation holds that analyzing both the powerful influences that groups and environments exert on collective behavior and how individuals vary within those collectives leads to a much more complete, nuanced, realistic, and useful understanding than does either level in isolation (Barker, 1987; Trickett, 1984).

This ecological orientation has been translated by community psychologists into both theoretical and practice principles. The most widely cited and used are those James G. Kelly (1966) borrowed from bio-ecology, which were later reinterpreted by Speer and Hughey (1995) for community organizing 
and community development. Kelly's principles include interdependence, which holds that change within one element or component of a community system has a ripple effect producing changes in other components of that system. For example, a new housing development creates changes, usually both good and bad, for schools, utilities, transportation, police, and businesses. Cycling of resources is exemplified in the way that resources are transformed as they flow through a community. The exchange of goods and services, and the value added to these as they encounter various community organizations, can reduce dependency on external public and private agencies. Adaptation addresses the ways in which organizations adapt to changes in their circumstances. One challenge to community development agencies is that they often become too dependent on outside grants and, in the name of organizational survival, they "chase grants," which result in a drift away from the organizational mission - an example of the deleterious side effects of some forms of adaptation. Lastly, succession, or stable and orderly change in a system, acknowledges the process through which discarded resources become new assets. Redevelopment of abandoned homes and transformation of vacant lots into a community park or garden are examples of this principle.

Murray Levine (Levine \& Perkins, 1997, pp. 144-146) has proposed five ecological principles of practice in community psychology:

1. A problem arises in a setting or in a situation; factors in the situation cause, trigger, exacerbate, and/or maintain the problem.

2. A problem arises because the problem-resolving (i.e. adaptive) capacity of the social setting is blocked.

3. To be effective, help has to be located strategically to the manifestation of the problem (this may seem obvious, especially to community developers, but psychological and other social service professionals often locate help passively in an office removed from the need).

4. The goals and values of the helping agent or service must be consistent with the goals and values of the setting.

5. The form of help should have potential for being established on a systematic basis, using the natural resources of the setting, or through introducing resources which can become institutionalized as part of the setting.

The ecological orientation has applicability to SC, particularly the bridging aspects at the collective organizational and network levels. The ecological orientation directs us to attend to numerous levels of influencegroups, organizations, community, and region. Whatever the level of analysis, community psychology looks to understand the characteristics of particular settings that influence, shape or constrain the behavior of individuals or 
collectives embedded within those settings. Through the ecological orientation, an understanding of the interplay of different ecological principles can help explain setting characteristics, which, in turn, can nurture or hinder the development of SC.

\section{Institutions and Networks}

We take as our starting point that SC at a community level of analysis is both the array of institutions or organizations in a given community and the network of relationships among them. The SC construct challenges community psychology and community development to take into account the full scope of community institutions, including the economic and social organizations that comprise the backdrop against which the individual experience of community life unfolds. Whether civic or economic, private or public, the institutional opportunity available to individuals in our communities comprises the extraindividual development capital through which sense of community and collective action (SC) unfold.

Our approach to conceptualizing and measuring SC at the community level is based on the premise that the physical presence and mix of institutions and organizations - together with their networks of relationship — constitute community level SC. Obscured in the legitimate excitement over features of the SC construct, such as trust, bonding, and attachment (concepts compatible with individual conceptions of community) are concerns for the institutional and organizational contexts that serve as the settings-the generators-that germinate, promote, and sustain connections within and across organizations and institutions. We believe that without the physical presence of the proper mix of institutions that are linked in an enduring way, SC will neither emerge nor generate positive community change. Putnam's work acknowledges the importance of institutions. He concludes that the functioning of institutions is the sole "consistent predictor" of citizen satisfaction (Putnam et al., 1993, p. 78). He reiterates the importance of institutions when, in Bowling Alone he asserts, "Like most issues, this one has two faces-one institutional and one individual...we need to address the supply side of opportunities for civic engagement and the demand for civic engagement" (Putnam, 2000, p. 405).

Putnam's description of the differential pattern of institutions across regions of Italy illustrates the relevance to well-being of horizontal versus vertical social relationships, and our interpretation is that it also points to the importance of conflict, power, and self-interest. In a similar vein, Berger and Neuhaus (1977), in advocating the developmental and empowering importance of mediating structures, argue for a focus on small-scale community institutions and their vital function of transporting individual concerns onto the community stage where they can engage in extra-individual transactions. Additionally, in an empirical investigation on the relational aspects of SC, Falk and Kilpatrick (2000) emphasize what they call "meso-level SC," which represents for them the 
community level manifestation of SC. We understand community institutions to be the full array of institutions, including civic, economic, public, and private. These concepts have been largely ignored by community psychologists, but they have been studied by community development researchers. For instance, Flora and colleagues have examined the role of "entrepreneurial social infrastructure" in the generation of community economic development (Flora, Sharp, Flora \& Newlon, 1997). In a study of 718 rural communities in the United States, they found that the presence of active civic organizations, broadly conceived, was a precursor to successful economic activity. This approach and its findings are tantalizing because they highlight the value of the community level of analysis and role of a variety of community institutions. Viewed more broadly in these ways, SC becomes a more robust concept for community development and community psychology by linking to economic capital and power (DeFilippis, 2001).

\section{Boundary Spanning and Resources}

As for networks, Granovetter (1973) and Burt (1999, 2000) highlight the value of "weak ties," gaps, or "structural holes" in networks, which serve as boundary spanning opportunities through which individuals can gain resources. Much as network analysis is conducted among individuals, we think it would be a good idea to extend network analyses to the assessment of the fabric of institution and organization relationships in communities. The outcomes of community development and community planning ventures may well hinge on the ability of community developers to detect and alter the network of institutional relationships that generate and control resources in communities. Flora and colleagues (Flora, 1998; Sharp and Flora, 1999) employ the concept of community network structure in the context of SC development in rural communities. The mapping of institutional or organizational presence in communities together with network analysis at the community level, similar to Sharp and Flora (1999), comes the closest to what we believe SC is at the community level. In many urban areas characterized by large-scale institutional abandonment and a landscape dominated by liquor outlets, check cashing and pay day loan offices, fast food restaurants, dilapidated and expensive grocery stores with limited fresh or healthful food, lottery and illicit gambling establishments, "adult" book stores and strip clubs, and substance abuse clinics - outside of the occasional community-engaged religious congregation, the institutional environment will provide scant opportunity for settings in which the individual experience of SC can flourish. This will be especially true when those few present institutions have thin or non-existent networks of relationship within the local community or beyond. The consequences of an institutional environment dominated by, say, liquor outlets, can be accompanied by more than an absence of SC; they may also breed violent crime (Speer, Gorman, Labouvie \& Ontkush, 1998).

This argument may be more easily heard in community development 
arenas, but these tend to be somewhat stunning and challenging assertions for many psychologists. However, they are fully compatible with community and environmental psychology (Trickett, 1984; Barker, 1987). At the heart of these notions is recognition of the importance of the ecological concept of interdependence between elements of a system and the concomitant embeddedness of one system within another. The idea of extra-individual interdependence invites consideration of those elements of a community that may be relatively rare, abundant, isolated from, or integrated with the larger community. It also invites consideration of how institutions and organizations can be intentionally developed to create interdependence where none previously existed. From an ecological perspective, the existence of a diverse mix of institutions linked in ways that facilitate boundary spanning creates an environment that provides a rich base of behavioral niches —ones that promote adaptation and serve as settings for the promotion of SC.

We presume that intentionally constituted settings are the incubators of relationships that yield SC in the form of broad based community organizations and productive networks of institutional relations. Once formed, these organizations can serve as bridges (Putnam, 2000) to engage in the often conflictual, but critical interchanges with other organizations and institutions. That is why so many community psychologists have studied the formation and functioning of, and participation in, different kinds of grassroots community improvement organizations (Dokecki et al., 2001; Fawcett et al., 1995; Florin \& Wandersman, 1984; Hughey et al., 1999; Kroeker, 1995; Maton \& Salem, 1995; Perkins et al., 1996; Pretty, 2002; Saegert \& Winkel, 1996; Sonn \& Fisher, 1998; Speer \& Hughey, 1995; Unger \& Wandersman, 1983). This qualitative and quantitative research has shed much light on the psychological, behavioral, and environmental predictors and effects of the different components of SC, going well beyond the usual emphasis on the demographic factors that permeates much of the literature. Such efforts represent an appropriate target for the collaboration between community psychology and community development.

\section{CONCLUSIONS}

Social capital is a compelling idea that has emerged as a genuine force in a variety of debates. It has become the focus for community building initiatives by foundations, a popular piece of political rhetoric, and importantly, a basis for interdisciplinary conversation. The concept has stimulated scholarly discourse and empirical research in several disciplines and the field of community development. Only recently has the concept appeared in psychology, which has been slower to embrace SC. However, community psychology has invested heavily in the related concepts of sense of community, empowerment, citizen participation, and neighboring - ideas with a rich history in psychology and relevance to SC. 
Returning to the definition of SC with which we began, we may differ from many other theorists in suggesting that, while both bridging and bonding among individuals and community institutions are important, they are not equally so. An overemphasis on bonding, or developing and maintaining a sense of community, can inhibit dealing with controversial issues and conflict, which is often necessary (Hughey \& Speer, 2002). Bonding within groups can, paradoxically, even lead to insularity, alienation of outsiders, and inhibit bridging to other groups (Burt, 1999). There is also a danger in over-reliance on bridging relationships with outside institutions, which may even come at the expense of community cohesion. It is through those bridging relationships that largerscale, "second order" change occurs, however. Bonding may help to support participation in organizations, but whether those organizations are empowering and, themselves, empowered, depends on their ability to bridge to other organizations and power structures.

DeFilippis (2001), following Bourdieu (1985), makes a similar argument in referring to the "myth of SC in community development." DeFilippis' point is an important one: in the current debate led by Putnam (2000), SC has been largely divorced from political and economic capital and so, conceived in purely social terms, provides no basis for large-scale or structural community change. A recent volume, edited by Saegert et al. (2001) and with a Foreword by Putnam, provides good examples of economic and political analyses of SC. Even though Saegert herself is a psychologist, however, there is little of what we are advocating, which is the melding of psychological analyses of "micro" SC with "meso" analyses of networks and "macro" analyses of institutional links to policy, power, and capital.

\section{A Call to Collaborate}

Given the applied community focus of community development and the individual focus of community psychology, future progress on the SC construct might be made by jointly exploring the reciprocal relationship between cognitive, behavioral, organizational, community action and community development variables. Generally speaking, there is tremendous energy at the boundary of systems, and the salutary conceptual and practical influence that interdisciplinary collaboration between community development and community psychology might bring to each discipline could be great. Focused on SC, joint research and practice endeavors could promote the positive aspects of SC to strengthen our disciplines. ${ }^{3}$ Community psychologists in less populated areas are professionally isolated and would benefit greatly by connecting to community developers. Likewise, community development researchers and professionals in or near major metropolitan areas and certain universities may be surprised to learn about the relevant work being done by community psychologists in their areas. 
We look forward to sharing SC-related ideas, data, and research and intervention approaches with community development researchers and practitioners. The bridging and networking we are calling for between community psychology and community development is exactly what SC is all about. Let us live up to our ideals and put SC theory into practice, not only in the community, but also at the level of our professional institutions and activities.

\section{NOTES}

1. Community organizations are called "mediating structures" because they provide a means for individuals and families to connect with, and collectively influence, macrosocietal structures of centralized government and other large, bureaucratic institutions.

2. According to its mission statement: "SCRA...is an international organization devoted to advancing theory, research, and social action. Its members are committed to promoting health and empowerment and to preventing problems in communities, groups, and individuals. Four broad principles guide SCRA:

- Community research and action requires explicit attention to and respect for diversity among peoples and settings;

- Human competencies and problems are best understood by viewing people within their social, cultural, economic, geographic, and historical contexts;

- Community research and action is an active collaboration among researchers, practitioners, and community members that uses multiple methodologies;

- Change strategies are needed at multiple levels in order to foster settings that promote competence and well-being." (http://www.apa.org/divisions/div27/, $3 / 11 / 02)$

3. Recent collaborative initiatives hold great promise for developing theory, research, and practice on SC and other concepts that overlap both community development and community psychology. Joint conference sessions have been held on such topics as SC, power, and empowerment, and the significance of place and the physical environment in community development. Future steps could be a special journal issue on each of the above topics and collaboration on joint papers and research projects. The major professional organizations of the two fields, the Community Development Society and Society for Community Research and Action (which has formed an Interdisciplinary Task Force to foster dialogue and collaboration with other fields and organizations), have agreed to consider a variety of joint ventures, including joint policy initiatives and possibly conference co-sponsorship. Perhaps the most ambitious initiative is the formation by SCRA of a group of university-based Community Action-Research Centers that would conduct a variety of on-going local projects. Modeled loosely on the Woods Hole Field Station in Marine Biology, researchers, students, and practitioners from any geographic and disciplinary base, either individually or in groups, could visit a center to learn from and contribute to the local projects. Action-research projects conducted at each Center would provide a great opportunity to compare SC processes in different political, economic, cultural, and social problem contexts.

\section{REFERENCES}

Argyris, C. 1993. Knowledge for action: A guide to overcoming barriers to organizational change. San Francisco: Jossey-Bass.

Barker, R. G. 1987. Prospecting in environmental psychology: Oskaloosa revisited. In D. Stokols \& I. Altman (eds.), Handbook of Environmental Psychology. New York: John Wiley \& Sons. 
Bateman, H. V. 2002. Sense of community in the school: Listening to students' voices. Pp. 161-179 in A. Fisher, C. Sonn, \& B. Bishop (eds.), Psychological Sense of Community: Research, Applications, and Implications. New York: Plenum.

Berger, P. L., \& R. J. Neuhaus. 1977. To empower people: The role of mediating structures in public policy. Washington, DC: American Enterprise Institute for Public Policy Research.

Borgatti, S. P., C. Jones, \& M.G. Everett. 1998. Network measures of social capital. Connections 21(2): 22-36.

Bourdieu, P. 1985. The forms of capital. Pp. 241-258 in J. Richardson (ed.), Handbook of Theory and Research for the Sociology of Education. New York: Greenwood.

Briggs, X. S. 1998. Brown kids in white suburbs: Housing mobility and the many faces of social capital. Housing Policy Debate 9: 177-221.

Brodsky, A. E., P. J. O'Campo, \& R. E. Aronson. 1999. PSOC in community context: Multi-level correlates of a measure of psychological sense of community in lowincome, urban neighborhoods. Journal of Community Psychology 27: 659-679.

Brown, B. B., \& D. D. Perkins. 1992. Disruptions in place attachment. Pp. 279-304 in I. Altman and S. Low (eds.), Place Attachment. New York: Plenum.

Burt, R. S. 1999. The social capital of opinion leaders. Annals of the American Academy of Political and Social Sciences 566: 37-64.

Burt, R. S. 2000. The network structure of social capital. Pp. 345-423 in R. Sutton \& B. Staw (eds.), Research in Organizational Behavior. Greenwich, CT: JAI Press.

Chavis, D. M., \& A. Wandersman. 1990. Sense of community in the urban environment: A catalyst for participation and community development. American Journal of Community Psychology 18: 55-82.

Chipuer, H. M., \& G. M. H. Pretty. 1999. A review of the sense of community index: Current uses, factor structure, reliability, and further development. Journal of Community Psychology 27: 643-658.

Christenson, J. A., \& J. W. Robinson, Jr. (eds.). 1989. Community Development in Perspective. Ames: Iowa State University Press.

Coleman, J. S. 1988. Social capital in the creation of human capital. American Journal of Sociology 94: S95-S120.

Dalton, J. H., M. J. Elias, \& A. Wandersman. 2001. Community Psychology: Linking Individuals and Communities. Belmont, CA: Wadsworth.

DeFilippis, J. 2001. The myth of social capital in community development. Housing Policy Debate 12: 781-806.

Dokecki, P. R., J. R. Newbrough, \& R. T. O’Gorman. 2001. Toward a community-oriented action research framework for spirituality: Community psychological and theological perspectives. Journal of Community Psychology 29(5): 497-518.

Falk, I., \& L. Harrison. 1998. Community learning and social capital: "Just having a little chat." Journal of Vocational Education and Training 50: 609-627.

Falk, I., \& S. Kilpatrick. 2000. What is social capital? A study of interaction in a rural community. Sociologia Ruralis 40: 87-110.

Fawcett, S. B., A. L. Paine-Andrews, V. T. Francisco, J. A. Schultz, K. P. Richter, R. K. Lewis, E. L. Williams, K. J. Harris, J. Y. Berkley, J. L. Fisher, \& C. M. Lopez. 1995. Using empowerment theory in collaborative partnerships for community health and development. American Journal of Community Psychology 23: 677-697. 
Fisher, A. T., \& C. C. Sonn. 2002. Psychological sense of community in Australia and the challenges of change. Journal of Community Psychology 30: 597-610.

Fisher, A. T., C. C. Sonn, \& B. Bishop (eds.). 2002. Psychological Sense of Community: Research, Applications, and Implications. New York: Plenum.

Flora, J. L. 1998. Social capital and communities of place. Rural Sociology 63: 481-506.

Flora, J. L., J. Sharp, C. Flora, \& B. Newlon. 1997. Entrepreneurial social infrastructure and locally initiated economic development in the non-metropolitan United States. Sociological Quarterly 38: 623-645.

Florin, P., \& A. Wandersman. 1984. Cognitive social learning and participation in community development. American Journal of Community Psychology 12: 689-708.

Foley, M. W., J. D. McCarthy, \& M. Chaves. 2001. Social capital, religious institutions, and poor communities. Pp. 215-245 in S. Saegert, J. P. Thompson \& M. R. Warren (eds.), Social Capital and Poor Communities. New York: Russell Sage Foundation.

Friedmann, J. 1992. Empowerment: The Politics of Alternative Development. Cambridge, MA: Blackwell.

Garcia, I., F. Giuliani, \& E. Wiesenfeld. 1999. Community and sense of community: The case of an urban barrio in Caracas. Journal of Community Psychology 27, 727-740.

Gittell, R., \& A. Vidal. 1998. Community Organizing: Building Social Capital as a Development Strategy. Thousand Oaks, CA: Sage Books.

Granovetter, M. 1973. The strength of weak ties. American Journal of Sociology 78: 1360-1380.

Hughey, J. B., \& J. W. Bardo. 1987. Social psychology dimensions of community satisfaction and quality of life: Some obtained relations. Psychological Reports 61: 239-246.

Hughey, J., \& P. W. Speer. 2002. Community, sense of community, and networks. Pp. 6984. in A. T. Fisher, C. C. Sonn, \& B. J. Bishop (eds.) Psychological Sense of Community: Research, Applications, and Implications. New York: KluwerAcademic/ Plenum.

Hughey, J., P. W. Speer, \& N. A. Peterson. 1999. Sense of community in community organizations: Structure and evidence of validity. Journal of Community Psychology 27: $97-113$.

Itzhaky, H., \& A. S. York. 2000. Sociopolitical control and empowerment: An extended replication. Journal of Community Psychology 28: 407-415.

Kelly, J. G. 1966. Ecological constraints on mental health services. American Psychologist 21: $535-539$.

Kretzmann, J.P., \& J. L. McKnight. 1993. Building Communities from the Inside Out: A Path Toward Finding and Mobilizing a Community's Assets. Chicago: ACTA.

Kroeker, C. J. 1995. Individual, organizational, and societal empowerment: A study of the processes in a Nicaraguan agricultural cooperative. American Journal of Community Psychology 23: 749-764.

Levine, M., \& D. V. Perkins. 1997. Principles of Community Psychology: Perspectives and Applications. $2^{\text {nd }}$ ed. New York: Oxford University Press.

Li, C. 1998. The contribution of common land to sense of community. Pp. 57-70. in J. Sanford \& B. R. Connell (eds.), People, Places and Public Policy. Edmond, OK: Environmental Design Research Association. 
Maton, K. I., \& D. A. Salem. 1995. Organizational characteristics of empowering community settings: A multiple case study approach. American Journal of Community Psychology 23: 631-656.

McMillan, D. W., \& D. M. Chavis. 1986. Sense of community: A definition and theory. Journal of Community Psychology 14: 6-23.

Miller, F., S. Tsemberis, G. Malia, \& D. Grega. 1980. Neighborhood satisfaction among urban dwellers. Journal of Social Issues 36: 101-117.

Narayan, D. 1999. Bonds and bridges: Social capital and poverty. Poverty Research Working Paper No. 2167. Washington, DC: World Bank. http://www.worldbank.org/ poverty/scapital/library/narayan.pdf

Perkins, D. D. 1995. Speaking truth to power: Empowerment ideology as social intervention and policy. American Journal of Community Psychology 23: 765-794.

Perkins, D. D., B. B. Brown, \& R. B. Taylor. 1996. The ecology of empowerment: Predicting participation in community organizations. Journal of Social Issues 52: 85-110.

Perkins, D. D., B. Crim, P. Silberman, \& B. B. Brown. In press. Community adversity and community development: Ecological and strengths-based theory, research and policies. In K. Maton, B. Ledbeater, C. Schellenberg \& A. Solarz (eds.), Investing in Children, Youth, Families and Communities: Strengths-Based Research and Policy. Washington, DC: American Psychological Association.

Perkins, D. D., P. Florin, R. C. Rich, A. Wandersman, \& D. M. Chavis. 1990. Participation and the social and physical environment of residential blocks: Crime and community context. American Journal of Community Psychology 18: 83-115.

Perkins, D. D., \& D.A. Long. 2002. Neighborhood sense of community and social capital: A multi-level analysis. Pp. 291-318 in A. Fisher, C. Sonn, \& B. Bishop (eds.), Psychological Sense of Community: Research, Applications, and Implications. New York: Plenum.

Perkins, D. D., A. Wandersman, R. C. Rich, \& R. B. Taylor. 1993. The physical environment of street crime: Defensible space, territoriality and incivilities. Journal of Environmental Psychology 13: 29-49.

Perkins, D. D., \& M. A. Zimmerman. 1995. Empowerment theory, research, and application. American Journal of Community Psychology 23: 569-579.

Pretty, G. M. H. 1990. Relating psychological sense of community to social climate characteristics. Journal of Community Psychology 18: 16-65.

Pretty, G. M. H. 2002. Young people's development of the community-minded self: Considering community identity, community attachment and sense of community. Pp. 183-203 in A. Fisher, C. C. Sonn, \& B. Bishop (eds.), Psychological Sense of Community: Research, Applications, and Implications. New York: Plenum.

Prezza, M., M. Amici, T. Roberti, \& G. Tedeschi. 2001. Sense of community referred to the whole town: Its relations with neighboring, loneliness, life satisfaction, and area of residence. Journal of Community Psychology 29: 29-52.

Putnam, R.D. 2000. Bowling Alone: The Collapse and Revival of American Community. New York: Simon \& Schuster.

Putnam, R. D., R. Leonardi, \& R. Y. Nanetti. 1993. Making Democracy Work: Civic Traditions in Modern Italy. Princeton, N.J.: Princeton University Press. 
Rappaport, J. 1987. Terms of empowerment/exemplars of prevention: Toward a theory for community psychology. American Journal of Community Psychology 15: 121148 .

Saegert, S. 1989. Unlikely leaders, extreme circumstances: Older black women building community households. American Journal of Community Psychology 17: 295-316.

Saegert, S., J.P. Thompson, \& M. R. Warren (eds.). 2001. Social capital and poor communities. New York: Russell Sage Foundation.

Saegert, S., \& G. Winkel. 1996. Paths to community empowerment: Organizing at home. American Journal of Community Psychology 24: 517-550.

Saegert, S., \& G. Winkel. 1998. Social capital and the revitalization of New York City's distressed inner city housing. Housing Policy Debate 9: 17-60.

Sampson, R.J. 1991. Linking the micro- and macro-level dimensions of community social organization. Social Forces 70: 43-64.

Sharp, J. S., \& J. L. Flora. 1999. Community structure, fields, and action: Network analysis of organizational interlocks and action in three rural communities. Manuscript from author.

Sonn, C. C., \& A. T. Fisher. 1998. Sense of community: Community resilient responses to oppression and change. Journal of Community Psychology 26: 457-472.

Speer, P. W., D. M. Gorman, E. W. Labouvie, \& M. J. Ontkush. 1998. Violent crime and alcohol availability: Relationships in an urban community. Journal of Public Health Policy 19: 303-318.

Speer, P. W., \& J. Hughey. 1995. Community organizing: An ecological route to empowerment and power. American Journal of Community Psychology 23: 729748 .

Speer, P. W., C. B. Jackson, \& N. A. Peterson. 2001. The relationship between social cohesion and empowerment: Support and new implications for theory. Health Education and Behavior 28: 716-732.

Trickett, E. J. 1984. Toward a distinctive community psychology: An ecological metaphor for the conduct of community research and the nature of training. American Journal of Community Psychology 12: 261-280.

Unger, D. G., \& A.Wandersman. 1983. Neighboring and its role in block organizations. American Journal of Community Psychology 11: 291-300.

Unger, D. G., \& A. Wandersman. 1985. The importance of neighbors: The social, cognitive, and affective components of neighboring. American Journal of Community Psychology 13: 139-170.

Varady, D. 1986. Neighborhood confidence: A critical factor in neighborhood revitalization? Environment and Behavior 18: 480-501.

Wandersman, A., \& G. A. Giamartino. 1980. Community and individual difference characteristics as influences on initial participation. American Journal of Community Psychology 8: 217-228.

Zimmerman, M. A., B. A. Israel, A. Schulz, \& B. Checkoway. 1992. Further explorations in empowerment theory: An empirical analysis of psychological empowerment. American Journal of Community Psychology 20: 707-727. 